\title{
Induction of oil palm (Elaeis gui neensisJ acq. var. Tenera) callogenesis and somatic embryogenesis from young leaf explants
}

\author{
Mondjeli Constantin ${ }^{1,2^{*}}$, Walter Ajambang Nchu ${ }^{1,2}$, Ntsomboh-Ntsefong Godswill ${ }^{2 *}$, Ni Made Armini Wiendi ${ }^{1}$, Ade \\ Wachjar $^{1}$, Ngando Ebongue Georges Frank ${ }^{2}$ \\ ${ }^{1}$ Department of Agronomy and Horticulture, Bogor Agricultural University 16680, Indonesia. \\ ${ }^{2}$ IRAD-Specialized Centre for Oil Palm Research of La Dibamba (CEREPAH) BP 243 Douala, Cameroon.
}

\section{ARTICLE INFO}

Article history:

Received on: $26 / 04 / 2015$

Revised on: $14 / 05 / 2015$

Accepted on: $04 / 06 / 2015$

Available online: 24/08/2015

Key words:

Somatic embryogenesis, in vitro culture, callogenesis, oil palm, young leaf explant, culture media.

\begin{abstract}
To determine the optimum medium for callus induction and somatic embryo formation, young leaf explants of oil palm (Elaeis guineensis Jacq.) var. Tenera were isolated from 9 and 13 years old trees. Young leaf explants of oil palm (Elaeis guineensis Jacq.) var. Tenera were isolated from 9 and 13 years old trees. These explants were inoculated onto solid modified MS and Eeuwens basal media containing 107.41 $\mu \mathrm{M}$ NAA and associated with 0 , $22.62,45.24$ or $67.86 \mu \mathrm{M} 2,4-\mathrm{D}$ and onto another MS basal medium with high concentration $450 \mu \mathrm{M}$ picloram or $450 \mu \mathrm{M} 2,4-\mathrm{D}$ in the presence of $0.03 \%$ (w/v) activated charcoal to induce embryogenic calli. After 28 weeks of culture, compact and pearly-white, globular callus was obtained from the leaf number five (L5). The 2,4-D and NAA media concentration combination (67.86 and $107.41 \mu \mathrm{M}$ respectively) constituted the optimal medium for embryogenic callus induction, while the media containing only NAA $(107.41 \mu \mathrm{M})$ induced the highest percentage of calli formation $(30.56 \%)$. After 36 weeks of culture, direct embryoids were obtained from leaf number six (L6) on the media containing the combination of NAA $(107.41 \mu \mathrm{M})$ and 2,4-D $(45.24 \mu \mathrm{M})$. Highest percentage $(38.33 \%)$ of direct shoot development was also obtained from the same media NAA $(107.41 \mu \mathrm{M})$.
\end{abstract}

\section{INTRODUCTION}

Tissue culture is the in vitro aseptic culture of cells, tissues, organs or whole plant under controlled nutritional and environmental conditions 1 often to produce the clones of plants. The resultant clones are true-to type of the selected genotype. The controlled conditions provide the culture an environment conducive for their growth and multiplication. This tissue culture propagation technique enables mass production of superior clonal palms with high yielding and other desirable traits. Several thousand hectares have been planted successfully in Southeast Asia with clonal oil palms. Clones yielded 9 to $11 \mathrm{t}$ oil/ha from the third year of production onwards, and a world record fruit yield of $50 \mathrm{t}$ fresh fruit bunches (FFB) per ha was recorded in the second year after the start of harvest 2. Currently there are about 21 commercial tissue culture laboratories in the world, involved in oil palm tissue culture, with Malaysia having the largest 3.

In 2009, oil palm clone producers in Malaysia produced 2.53 million ramets. The estimated world production of oil palm tissue culture plantlets is reported for about 3,5 million ramets per year. However, this production of ramets is far below the amount needed by the industry 4 . Due to high demand of

\footnotetext{
* Corresponding Author

Email: ntsomboh@yahoo.fr
}

demand of tissue culture plantlets, oil palm propagation by in vitro technique offers a very attractive investment venture in which more than one hundred million of tissue culture plantlets are needed per year 5 . The success of many in vitro techniques in plants depends on the success of plant regeneration. In fact, the application of some techniques such as in vitro mutant and protoplast fusion are suitable to cell culture but may be limited because of the inability to regenerate plants. A vast reservoir of genetic variability is common from in vitro plant regeneration 6. Totipotence was first demonstrated by the use of Nicotiana tabacum serving as a model for in vitro studies 7 . The first production of haploid plants by in vitro culture of excised anthers was achieved by using Datura innoxia 8. The first somatic hybrid was obtained from two Nicotiana species, $N$. glauca and N. Langsdorfii 9. The initiation and development of embryos from somatic tissues in plant culture was first recognized in the culture of Daucus carota tissue 1011 12.

Oil palm propagation through tissue culture is also widely used. Initially tissue culture techniques were used to propagate elite oil palm clones 13 Several explant sources have been used to perform tissue culture. These include mature embryos 14, inflorescences 15, roots 13, seedlings 16, and young leaves 1718 . Unfortunately some early aberrations were observed from plants produced 19. However, oil palm tissue culture techniques have undergone continuous improvement in recent years. This has resulted in the production of clonal palms with minimal abnormality (less than 5\%) 20, 21. 
Moreover, complete plants have been successfully regenerated from various explants of oil palm 22. Although these skills are applied, the frequencies for complete plant regeneration from some explants are still inefficient 23. The low response of embryogenesis is influenced mainly by genotype and donor plant age 24 , in addition to the influence of the appropriate media and explants source.

Best explants are from young tissues still undergoing cell division and generally form callus more readily than those from older plant parts, where the meristematic cell activities are reduced or lost. In general, the more juvenile the explant material, the greater the likelihood of success 25, 26. Embryogenesis rates of oil palm usually average less than $5 \%$ per ortet 27.

In terms of performance, it was reported 28 that clonal plantlets derived from selected ortets were significantly superior to commercial DxP seedlings. Thus protocol improvements are still needed for tissue culture of oil palm plant propagation. It is in this light that this study was carried out to determine the optimum medium for callus induction and somatic embryo formation from young leaf explants of oil palm of Tenera variety. Results of this study could contribute to the development of elite oil palm plant propagation for seedlings production.

\section{MATERIALS AND METHODS}

\subsection{Study site}

This work was carried out in the Laboratory of Plant Biotechnology and Tissue Culture, Faculty of Agriculture, Bogor Agricultural University, Indonesia.

\subsection{Plant materials and equipment}

The starting materials for callus induction were immature leaves isolated from Tenera donor palms. The selected trees were about 9 and 13 years old.

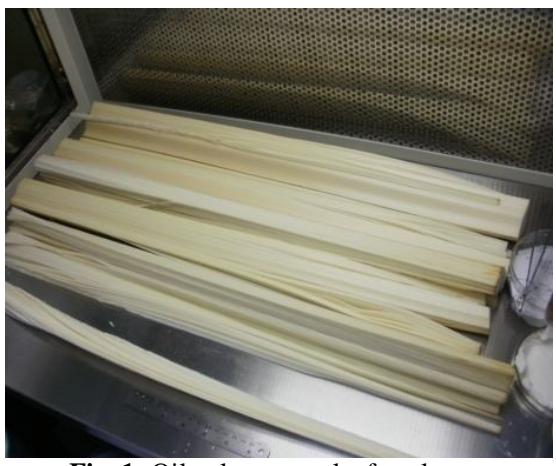

Fig. 1: Oil palm young leaf explants.

The donor palm was selected according to some phenotypical characters such as fresh bunch number, height, vigor, and health conditions. The vegetative material samples were collected from Bogor Agricultural University Experimental Station of Cikabayan oil palm plantation. The explants used in this study are shown in Figure 1.

\subsection{Media preparation}

Two different modified basal nutrient media, Murashige and Skoog medium 29 and Eeuwens and Blake medium 30, containing macro and micro salts (Table $1 \& 2$ ), were used for callus induction and embryo proliferation. These media were supplemented with NAA, glutamine, asparagine, 2,4-D and Picloram.

Table 1: Murashige and Skoog (MS) medium composition used in the experiment.

\begin{tabular}{|c|c|c|c|c|}
\hline Stock & Compound & $\begin{array}{c}\begin{array}{c}\text { Stock solution } \\
\text { concentration } \\
(\mathrm{g} / \mathrm{l})\end{array} \\
\end{array}$ & $\begin{array}{c}\text { Pipette } \\
\text { volume } \\
\text { (ml/l media) } \\
\end{array}$ & $\begin{array}{c}\text { Media } \\
\text { concentration } \\
(\mathrm{mg} / \mathrm{l}) \\
\end{array}$ \\
\hline $\mathrm{A}$ & $\mathrm{NH}_{4} \mathrm{NO}_{3}$ & 82.500 & 20 & 1650 \\
\hline B & $\mathrm{KNO}_{3}$ & 95.000 & 20 & 1900 \\
\hline \multirow[t]{5}{*}{$\mathrm{C}$} & $\mathrm{KH}_{2} \mathrm{PO}_{4}$ & 34.000 & 5 & 170 \\
\hline & $\mathrm{H}_{3} \mathrm{BO}_{3}$ & 1.240 & & 6.2 \\
\hline & $\mathrm{Na}_{2} \mathrm{MoO}_{4} \cdot 2 \mathrm{H}_{2} \mathrm{O}$ & 0.050 & & 0.250 \\
\hline & $\mathrm{CoCl}_{2} \cdot \mathrm{H}_{2} \mathrm{O}$ & 0.005 & & 0.025 \\
\hline & $\mathrm{Kl}$ & 0.166 & & 0.830 \\
\hline $\mathrm{D}$ & $\mathrm{CaCl}_{2} \cdot 2 \mathrm{H}_{2} \mathrm{O}$ & 88.000 & 5 & 440 \\
\hline \multirow[t]{4}{*}{$\mathrm{E}$} & $\mathrm{MgSO}_{4} \cdot 7 \mathrm{H}_{2} \mathrm{O}$ & 74.000 & 5 & 370 \\
\hline & $\mathrm{MnSO}_{4} \cdot 4 \mathrm{H}_{2} \mathrm{O}$ & 4.460 & & 22.3 \\
\hline & $\mathrm{ZnSO}_{4} \cdot 7 \mathrm{H}_{2} \mathrm{O}$ & 1.720 & & 8.6 \\
\hline & $\mathrm{CuSO}_{4} .5 \mathrm{H}_{2} \mathrm{O}$ & 0.005 & & 0.025 \\
\hline \multirow[t]{2}{*}{$\mathrm{F}$} & $\mathrm{Na}_{2}$ EDTA. $2 \mathrm{H}_{2} \mathrm{O}$ & 3.730 & 10 & 37.3 \\
\hline & $\mathrm{FeSO}_{4} .7 \mathrm{H}_{2} \mathrm{O}$ & 2.780 & & 27.8 \\
\hline \multirow[t]{4}{*}{ VIT } & Thiamine & 0.010 & 10 & 0.1 \\
\hline & Niacin & 0.050 & & 0.5 \\
\hline & Pyrotoxine & 0.050 & & 0.5 \\
\hline & Glycin & 0.200 & & 2.0 \\
\hline Myo & Myo inositol & 10.000 & 10 & 100 \\
\hline
\end{tabular}

Table 2: Eeuwens and Blake medium $\left(\mathrm{Y}_{3}\right)$ composition.

\begin{tabular}{|c|c|c|c|c|}
\hline Stock & Compound & $\begin{array}{c}\text { Stock solution } \\
\text { concentration } \\
(\mathrm{g} / \mathrm{l})\end{array}$ & $\begin{array}{c}\text { Pipette } \\
\text { volume } \\
(\mathrm{ml} / \mathrm{l} \\
\text { media) }\end{array}$ & $\begin{array}{c}\text { Media } \\
\text { concentration } \\
(\mathrm{mg} / \mathrm{l})\end{array}$ \\
\hline \multirow[t]{2}{*}{$\mathrm{A}$} & $\mathrm{NH}_{4} \mathrm{Cl}$ & 26.750 & 20 & 535 \\
\hline & $\mathrm{KCl}$ & 74.600 & & 1492 \\
\hline B & $\mathrm{KNO}_{3}$ & 40.400 & 20 & 2020 \\
\hline \multirow[t]{6}{*}{$\mathrm{C}$} & $\mathrm{NaH}_{2} \mathrm{PO}_{4} \cdot 2 \mathrm{H}_{2} \mathrm{O}$ & 55.200 & 5 & 276 \\
\hline & $\mathrm{H}_{3} \mathrm{BO}_{3}$ & 0.620 & & 3.1 \\
\hline & $\mathrm{Na}_{2} \mathrm{MoO}_{4} \cdot 2 \mathrm{H}_{2} \mathrm{O}$ & 0.048 & & 0.24 \\
\hline & $\mathrm{CoCl}_{2} \cdot 6 \mathrm{H}_{2} \mathrm{O}$ & 0.048 & & 0.24 \\
\hline & $\mathrm{Kl}$ & 1.660 & & 8.30 \\
\hline & $\mathrm{NiCl}_{2} \cdot 6 \mathrm{H}_{2} \mathrm{O}$ & 0.0048 & & 0.024 \\
\hline $\mathrm{D}$ & $\mathrm{CaCl}_{2} .2 \mathrm{H}_{2} \mathrm{O}$ & 58.800 & 5 & 294 \\
\hline \multirow[t]{4}{*}{$\mathrm{E}$} & $\mathrm{MgSO}_{4} \cdot 7 \mathrm{H}_{2} \mathrm{O}$ & 49.400 & 5 & 247 \\
\hline & $\mathrm{MnSO}_{4} \cdot \mathrm{H}_{2} \mathrm{O}$ & 2.240 & & 11.2 \\
\hline & $\mathrm{ZnSO}_{4} .7 \mathrm{H}_{2} \mathrm{O}$ & 1.440 & & 7.2 \\
\hline & $\mathrm{CuSO}_{4} .5 \mathrm{H}_{2} \mathrm{O}$ & 0.050 & & 0.25 \\
\hline \multirow[t]{2}{*}{$\mathrm{F}$} & NaEDTA. $2 \mathrm{H}_{2} \mathrm{O}$ & 3.720 & 10 & 37.2 \\
\hline & $\mathrm{FeSO}_{4} .7 \mathrm{H}_{2} \mathrm{O}$ & 1.390 & & 13.9 \\
\hline \multirow[t]{5}{*}{ VIT } & Thiamine & 0.050 & 10 & 0.5 \\
\hline & Niacin & 0.005 & & 0.05 \\
\hline & Pyrotoxine & 0.005 & & 0.05 \\
\hline & $\mathrm{CaP}$ & 0.005 & & 0.05 \\
\hline & Biotin & 0.005 & & 0.05 \\
\hline Myo & Myo inositol & 10.000 & 10 & 100 \\
\hline
\end{tabular}

\subsection{Sterilization compounds}

Standard sterilizing agents such as alcohol (5\%; $10 \%$ and $70 \%$ ), Sodium hypochlorite (bleach) $(5.25 \% \mathrm{NaClO})$, detergent, fungicide (Dithane M-45 2g/l, Agrept 2g/l) and antibiotic (Amoxicillin 1g/l), aquades steril were used in the experiment. 


\subsection{Laboratory equipment and tools}

The equipment and tools used in the experiment are pipette fillers ( $1 \mathrm{ml}$ and $10 \mathrm{ml}$ ), autoclave 21 , wrapping plastic, 250 and $270 \mathrm{ml}$ glass bottles (baby food jar), magnetic stirrer, magnetic shaker, digital analytical scale balance, bunsen burners, erlenmeyer volumetric flask $(250,500$ and $1000 \mathrm{ml})$, graduated cylinders (100 and $500 \mathrm{ml}$ ), hot plate, laminar air flow cabinet, spatula, pincer, sterilized blades, scalpel (knife), forceps, $\mathrm{pH}$ meter, Petri dishes, thermometer, pot holder, refrigerator, gas ring, labeler, cup holders (1000 and $2000 \mathrm{ml}$ ), towel, papers, sprayer, disposable mask, and disposable hand gloves.

\subsection{Methods}

\subsubsection{Oil palm tree sampling and explant processing}

The donor palm used for explants isolation was a 9 years old Tenera variety. After the palm was identified, the spear was carefully removed by using a curved knife and with the help of a specially designed protocol to ensure that the donor palm and the candidate spear are not damaged during the isolation process. As soon as the spear was isolated from the palm, it was sprayed with 96\% alcohol, wrapped and placed inside a sampling bag. The protected spear (Figure 2a) was then taken immediately to the laboratory for processing.

The spear is a cluster of unopened young leaves or fronds which differ in age (Figure $2 b$ ). The leaves were carefully removed from the spear in laminar air flow cabinet of the dissecting or plant preparation room and grouped per cluster (Figure 2d). The leaves were then soaked in a $10 \% \mathrm{NaOCl}$ (household bleach) solution for 10 minutes (sterilization) and rinsed three times in sterile distilled water. Each cluster of leaves was then soaked in $10 \%$ sterile sucrose solution.

Leaves were sliced into $1 \mathrm{~cm}$ length and inoculated onto callus induction media using four explants per vessel. From one spear, around 3600 pieces of explants were extracted.

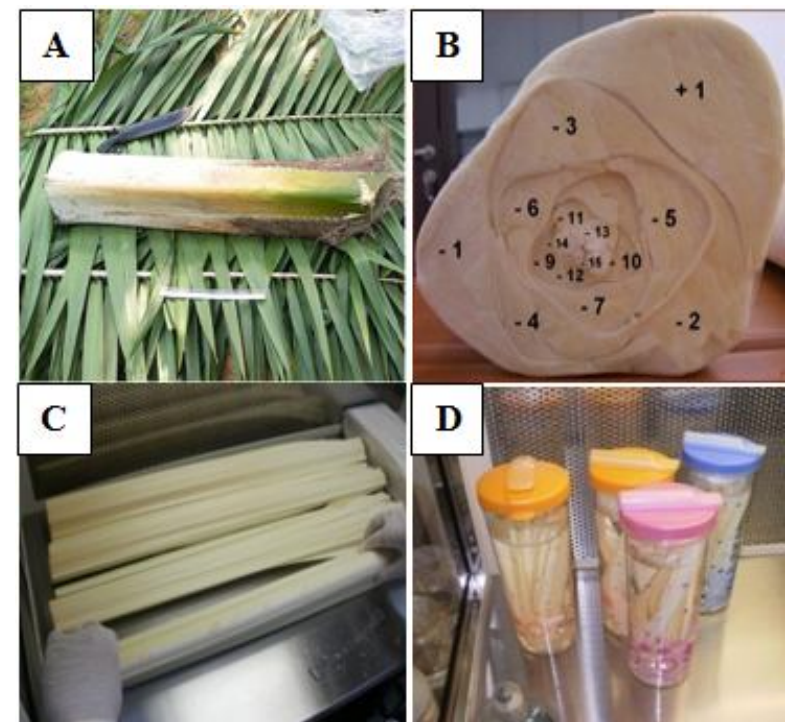

Fig. 2: Young leaf samples processed from the field to laboratory.

A. Isolated spear, B. Young leaf clusters in the spear, C. Isolated cluster of young leaves, D. Young leaves soaked in sucrose solution after sterilization.

\subsection{Callogenesis mixing medium}

Ten treatments were applied: C1, C2, C3, C4, C5, C6 for Murashige and Skoog medium and M1, M2, M3, M4, for Eeuwens and Blake medium $\left(\mathrm{Y}_{3}\right)$. The tested media compositions were as follow:

$$
\begin{aligned}
& \mathrm{C} 1=\mathrm{MS}+0 \mu \mathrm{M} 2,4-\mathrm{D}+107.41 \mu \mathrm{M} \text { NAA } \\
& \mathrm{C} 2=\mathrm{MS}+22.62 \mu \mathrm{M} 2,4-\mathrm{D}+107.41 \mu \mathrm{M} \text { NAA } \\
& \mathrm{C} 3=\mathrm{MS}+45.24 \mu \mathrm{M} 2,4-\mathrm{D}+107.41 \mu \mathrm{M} \text { NAA } \\
& \mathrm{C} 4=\mathrm{MS}+67.86 \mu \mathrm{M} 2,4-\mathrm{D}+107.41 \mu \mathrm{M} \text { NAA } \\
& \mathrm{C} 5=\mathrm{MS}+450 \mu \mathrm{M} \text { picloram } \\
& \mathrm{C} 6=\mathrm{MS}+450 \mu \mathrm{M} 2,4-\mathrm{D} \\
& \mathrm{M} 1=\mathrm{Y} 3+0 \mu \mathrm{M} 2,4-\mathrm{D}+107.41 \mu \mathrm{M} \text { NAA } \\
& \mathrm{M} 2=\mathrm{Y} 3+22.62 \mu \mathrm{M} 2,4-\mathrm{D}+107.41 \mu \mathrm{M} \text { NAA } \\
& \mathrm{M} 3=\mathrm{Y} 3+45.24 \mu \mathrm{M} 2,4-\mathrm{D}+107.41 \mu \mathrm{M} \text { NAA } \\
& \mathrm{M} 4=\mathrm{Y} 3+67.86 \mu \mathrm{M} 2,4 \mathrm{D}+107.41 \mu \mathrm{M} \text { NAA }
\end{aligned}
$$

The $\mathrm{pH}$ of nutrient media $(\mathrm{C} 1, \mathrm{C} 2, \mathrm{C} 3, \mathrm{C} 4, \mathrm{M} 1, \mathrm{M} 2, \mathrm{M} 3$, and M4) was adjusted to 5.7 with $1 \mathrm{~N} \mathrm{NaOH}$ or $\mathrm{HCl}$ before the purified agar was added and autoclaved. For each medium, 5\% of commercial sugar and $0.9 \%$ of purified agar to make solid medium were used. For C5 and C6 media, 3\% of commercial sugar was used while the $\mathrm{pH}$ was adjusted to 5.8 before adding $0.3 \mathrm{~g} / \mathrm{l}$ charcoal and $0.9 \%$ of purified agar. The Media were dispensed into culture jars $(250 \mathrm{ml})$ and covered with heat resistant plastic. Then media were autoclaved for 20 minutes at $121{ }^{\circ} \mathrm{C}$ and $0.1 \mathrm{bar}$ (17.5 psi).

The experimental design was a factorial randomized complete block design with 3 replications. Each treatment was applied in 30 jars so that a total of 960 explants could be used per replication. The first factor considered was the rank of leaf with 5 levels (L-5, L-6, L-7, L-8, L-9) and the second factor was the concentration of the tested growth hormone with 10 levels $(\mathrm{C} 1$, C2, C3, C4, C5, C6, M1, M2, M3, M4). Another factor, the type of basal media solution with two levels (MS and Eeuwens media) was also taken into account.

\subsection{Environmental culture conditions}

Cultures were incubated under darkness to induce callus in a temperature-controlled room at $28 \pm 1{ }^{\circ} \mathrm{C}$. Observations were done every week for the percentage of contamination and every four weeks for the percentage of explant developing callus, the percentage of embryogenic callus, and the percentage of embryoid. Qualitative variables recorded were the color of explant (browning), the color of callus, and the callus structures (nodular, root-like, and embryogenic). As soon as calli were initiated, they were transferred in the new same media composition. The subculture of the initial explant for callus initiation was done at 12 week intervals, while the initiated callus was subcultured at 8 week intervals.

\subsection{Culture conditions of embryos}

The embryoid stage marks the beginning of the light phase of the oil palm tissue culture process. The embryogenic cells and embryoid cultures were transferred from continuous dark 
culture to continuous light culture room for incubation with more light intensity of 1000 lux at $29 \pm 1^{\circ} \mathrm{C}$. The number of embryo cells was recorded.

\subsection{Embryogenesis mixing medium}

Calli are undifferentiated tissues which have the ability to give rise to unspecialized cells (embryogenic Calli) that are meristematic and can produce embryoids under good conditions. As soon as embryogenic calli or embryoids were produced, they were transferred to embryoid media for their proliferation or multiplication and maturation. These media consisted of the same basal medium composition but with $25 \%$ of gradually reduced concentration of 2,4-D and NAA from the $3^{\text {rd }}$ to $4^{\text {th }}$ subcultures. Each subculture was done after 6 week intervals. The flow chart of subcultures is given in figure 3 .

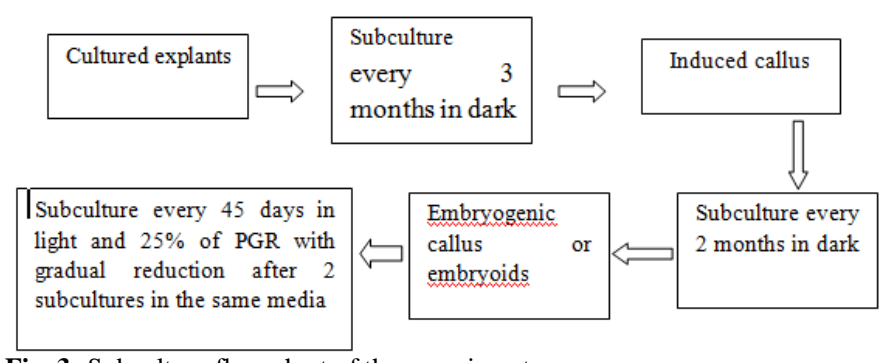

Fig. 3: Subculture flow chart of the experiment.

\subsection{Data Analysis}

The ANOVA of data obtained was done using Excel software. The means were separated with Student-Newman-Keuls tests at the 0.01 and 0.05 levels of probability, respectively. The F-test was used to show significant differences among means.

\section{RESULTS AND DISCUSSION}

\subsection{Callus induction of young leaf explants}

The leaf explants were swollen after 2-3 weeks in callus induction culture medium. It has been reported 31 that callus production is always extremely slow for palms. This assertion was in harmony with our result. In fact callus induction was first observed from young leaf number nine (L-9) after 8-12 weeks of culture on medium $\mathrm{C} 1$ containing only NAA $(107.41 \mu \mathrm{M})$ as plant growth regulator.

These calli appeared at the top of explant surface on the vascular region as shown in Figure 4. Another type of callus was observed. It consisted of hard root-like callus which appeared to develop from the tips of explants as shown in Figure 5. Calli were grey to dark-grey and white in color and had a friable consistency. After the $39^{\text {th }}$ week, callus production varied from $1.39 \%$ to $30.56 \%$ depending on the combination of NAA and 2,4-D; the rank of leaf and subsequently the type of basal media (Table 3). A similar type of callogenesis was reported by 32 in zygotic embryo of oil palm. $\mathrm{C} 1$ media gave the best percentage of explant bearing callus, and the young leaf rank (L-9) was more responsive than older leaf explants (L-5, L-6, L-7, and L-8). From the obtained calli, $87 \%$ were induced from MS media and the other $13 \%$ were observed from Eeuwens media.

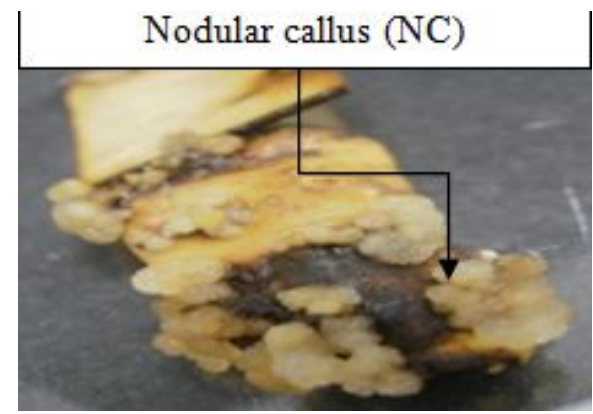

Fig. 4: Friable NC proliferation from young leaf explants 24 weeks after inoculation.

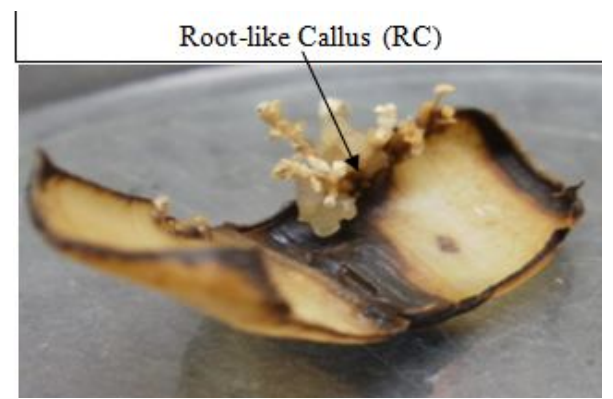

Fig. 5: Root-like callus initiation from young leaf explant after 24 weeks

According to the statistical analysis, it was observed in this study that there is a very highly significant influence of the type of medium concentration (Table 4). The $\mathrm{C} 1$ media composed of MS as basal medium and NAA as plant growth regulator was optimal for callogenesis response from immature leaf explant of oil palm (Table 5). This result showed that the presence of NAA only at the concentration of $107.41 \mu \mathrm{M}$ in MS basal medium promoted callus initiation and proliferation. However, by adding 2,4-D in the same media, the ability of meristematic cells activity to induce callogenesis was reduced. Another worker 33 reported that, auxins have multiple roles in tissue culture according to their chemical structure, concentration, and the plant tissue being affected. Auxins influence callus production, cell elongation, and cell division in cambium tissue. No significant difference was observed between the leaf ranks of oil palm (Elaeis guineensis Jacq.) var. Tenera at the threshold $\alpha=0.05$ for callus induction (Table 6). This result showed that all the young leaf ranks (L-5, L6, L-7, L-8, L-9) of the spear gave the same response for callogenesis and can be easily exploited for callus induction purpose in embryogenesis experiments. In other words, the young leaf cells from the spear are potentially totipotent, competent to receive the signal that triggers the callogenesis pathway. It was reported that, the presence of auxin in the earlier age of inflorescence explants stimulated callus induction 0. According to 22 , the success in obtaining callus formation was likely due to the use of very young explants, the presence of suitable concentration of the auxin, and strict subculture regime. 
Table 3: Influence of various medium composition (NAA and 2,4-D) and young leaf rank of oil palm (E. guineensis) cv.Tenera spear on the percentage of explant bearing callus after 39 weeks.

\begin{tabular}{|c|c|c|c|c|c|c|c|c|c|c|}
\hline \multirow{3}{*}{$\begin{array}{l}\text { Rank of } \\
\text { leaf on } \\
\text { the spear }\end{array}$} & \multicolumn{10}{|c|}{ Type of medium composition } \\
\hline & \multicolumn{6}{|c|}{ MS medium } & \multicolumn{4}{|c|}{ Eeuwens medium } \\
\hline & $\overline{C 1}$ & $\mathrm{C2}$ & $\mathbf{C 3}$ & $\mathrm{C4}$ & C5 & C6 & M1 & M2 & M3 & M4 \\
\hline & \multicolumn{10}{|c|}{ Percentage (\%) of callogenesis } \\
\hline $\mathrm{L}-5$ & 11.11 & 0 & 0 & 2.78 & 0 & 0 & 1.39 & 0 & 0 & 0 \\
\hline L-6 & 1.39 & 0 & 0 & 0 & 0 & 0 & 0 & 0 & 0 & 0 \\
\hline L-7 & 6.94 & 0 & 0 & 1.39 & 0 & 0 & 0 & 0 & 0 & 0 \\
\hline L-8 & 12.50 & 0 & 0 & 0 & 0 & 0 & 1.39 & 0 & 0 & 0 \\
\hline L-9 & 30.56 & 0 & 0 & 0 & 0 & 0 & 6,94 & 0 & 0 & 0 \\
\hline
\end{tabular}

Note: $\mathrm{C} 1-4=\mathrm{MS}+(0,22.62,45.24,67.86 \mu \mathrm{M}) 2,4-\mathrm{D}+107.41 \mu \mathrm{M}$ NAA, C5= MS+450 $\mu \mathrm{M}$ picloram, $\mathrm{C} 6=\mathrm{MS}+450$ $\mu \mathrm{M}, \mathrm{M} 1-4=\mathrm{Y} 3+(0,22.62,45.24,67.86 \mu \mathrm{M}) 2,4-\mathrm{D}+107.41 \mu \mathrm{M}$ NAA. $\mathrm{L}-\mathrm{x}=$ leaf number in the spear.

Table 4: NOVA of callus induction from immature leaf explant of oil palm

\begin{tabular}{llllll}
\hline Source & DF & Type III SS & Mean Square & F Value & Pr> F \\
\hline Replication & 2 & 28.84 & 14.42 & 3.60 & 0.0310 \\
Medium & 9 & 196.37 & 21.82 & 5.45 & $<.0001$ \\
Leafrank & 4 & 12.71 & 3.18 & 0.79 & 0.5324 \\
Medium*leafrank & 36 & 71.03 & 1.97 & 0.49 & 0.9910 \\
Error & 98 & 392.49 & 4.005 & & \\
Corrected Total & 149 & 701.44 & & & \\
\hline
\end{tabular}

Table 5: Mean number of young leaf explants of Tenera oil palm bearing callus per media

\begin{tabular}{|c|c|}
\hline Type of medium composition & Mean number of callogenesis per media \\
\hline $\mathrm{C} 1$ & $\begin{array}{c}3.86 \quad \mathrm{a} \\
\end{array}$ \\
\hline $\mathrm{C} 2$ & $0 \quad b$ \\
\hline $\mathrm{C} 3$ & $0 \quad b$ \\
\hline $\mathrm{C} 4$ & $0,40 \mathrm{~b}$ \\
\hline $\mathrm{C} 5$ & $0 \quad b$ \\
\hline C6 & $0 \quad b$ \\
\hline M1 & $0.53 \mathrm{~b}$ \\
\hline M2 & $0 \quad \mathrm{~b}$ \\
\hline M3 & 0 \\
\hline M4 & $\mathrm{b}$ \\
\hline
\end{tabular}

Note: Means with the same letter are not significantly different according to Student-Newman Keuls test $(\mathrm{P}<0.05) . \mathrm{C} 1-4=\mathrm{MS}+(0,22.62,45.24,67.86 \mu \mathrm{M}) 2,4-\mathrm{D}+107.41 \mu \mathrm{M}$ NAA, $\mathrm{C} 5=\mathrm{MS}+450 \mu \mathrm{M}$ picloram, $\mathrm{C} 6=$ $\mathrm{MS}+450 \mu \mathrm{M}, \mathrm{M} 1-4=\mathrm{Y} 3+(0,22.62,45.24,67.86 \mu \mathrm{M}) 2,4-+107.41 \mu \mathrm{M}$ NAA

Table. 6: Effect of the spear leaf rank of oil palm var. Tenera on callogenesis after 39 weeks in medium

\begin{tabular}{cc}
\hline Rank of leaf on the spear & Mean number of callogenesis per leaf \\
\hline L-5 & $0.70 \mathrm{a}$ \\
L-6 & $0.07 \mathrm{a}$ \\
L-7 & $0.40 \mathrm{a}$ \\
L-8 & $0.33 \mathrm{a}$ \\
L-9 & $0.90 \mathrm{a}$ \\
\hline
\end{tabular}

Note: Means with the same letter are not significantly different with Student-Newman-Keuls test $(\mathrm{P}<0.05) . \mathrm{L}-\mathrm{x}=$ leaf number in the spear.

\subsection{Embryogenesis of young leaf explants}

After approximately 28 weeks of culture, a small, compact and pearly-white, globular callus was observed in culture derived from the leaf number five (L-5) (Figure 6). As compared to other young leaves, L-5 is the oldest from the isolated spear and was competent to initiate embryogenic callus. These pearly-white cells were obtained on $\mathrm{C} 4$ media containing MS basal medium supplemented with the combination of NAA $(107.41 \mu \mathrm{M})$ and 2,4-D $(67.86 \mu \mathrm{M})$. The success in obtaining embryogenic callus was likely due to the use of potential competent young leaves (L$5)$ which in the presence of suitable concentration of 2,4-D (67.86 $\mu \mathrm{M})$ and strict subculture regime, triggered the embryogenic induction pathway. Similar cell structures were reported in immature inflorescences of coconut 35 and in immature inflorescences of the oil palm [22]. From all the obtained calli, just $3.63 \%$ of embryogenic calli were produced. Other workers 36 observed that the crossing type of plants or genotypes play an important role in somatic embryogenesis. After 36 weeks of culture, another different mass cell was observed from explants. It consisted of direct big, compact and pearly-white globular callus (direct embryoid) obtained from leaf number six (L-6) on the C3 medium containing the combination of NAA and 2,4-D (Figure 7).

From that mass tissue 15 single cells were obtained. In fact, the increase of 2,4-D concentration up to $45.24 \mu \mathrm{M}$ stimulated direct embryoid cells to be induced from the young leaves L- 6 of the spear of oil palm. The same type of direct pearlywhite globular cells was reported by 37 . Indirect embryogenesis is 
more common 38. While direct embryogenesis is more desirable, it is more difficult to achieve as the conditions necessary are more critical than those required to produce embryogenic callus. After 4 subsequent subcultures on the same medium with gradual reduction of auxin concentration, growth of these embryogenic calli and embryoids showed no further development. The mass of tissue maintained this characteristic when cultured in the same medium without changing the medium composition during the time required for this study.

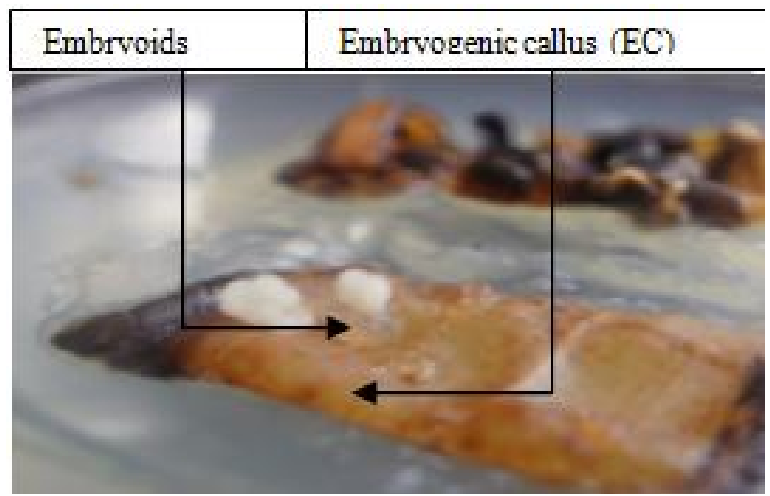

Fig. 6: EC obtained from young leaf $n^{0}-5$ of oil palm after 28 weeks of culture on $\mathrm{C} 4$ media

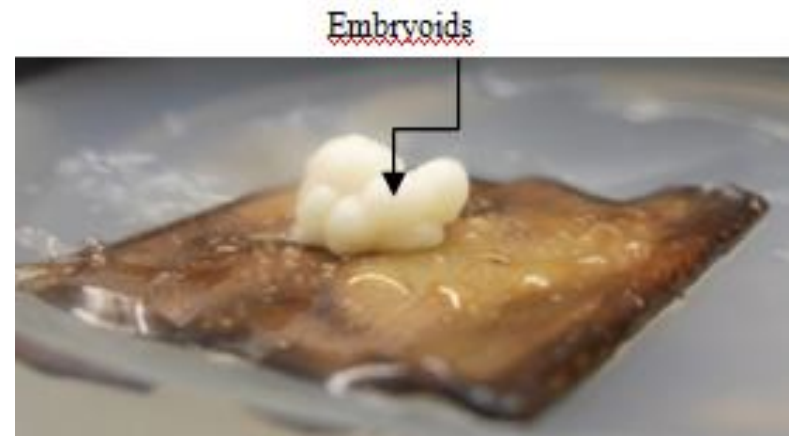

Fig. 7: Direct embryoid cells obtained from young leaf $n^{0}-6$ of oil palm in C3 media after 36 weeks of culture.

\section{CONCLUSION}

The present study successfully describes in vitro somatic embryogenesis protocol of young leaf explants of oil palm. MS basal medium containing only NAA $(107.41 \mu \mathrm{M})$ was the optimal medium for callus induction, while MS basal medium containing the combination of NAA $(107.41 \mu \mathrm{M})$ and 2,4-D $(45.24 \mu \mathrm{M})$ was optimal for direct embryoids production of young leaf explants of oil palm var. Tenera. No significant difference was observed between the young leaf ranks of oil palm (Elaeis guineensis Jacq.) var. Tenera for callogenesis. However, the leaf rank L-5 gave the best response for embryogenic callus formation and L-6 for direct embryo production.

\section{ACKNOWLEDGEMENTS}

Our sincere thanks are extended to Indonesian Palm Oil Board (IPOB) and Institute of Agricultural Research for Development of Cameroon for their consistent financial backing of this research. We are grateful to Bogor Agricultural University (IPB) for providing oil palm plant material candidates and tissue culture laboratory for this study.

\section{REFERENCES}

1. Thorpe T. History of plant tissue culture. J. Mol. Microbial Biotechnol. 2007; 37: 169-180.

2. Mutert E and Fairhurst TH. Oil Palm Clones: Productivity Enhancement for the Future. Better Crops International. 1999; 13 (1): 45-47.

3. Rajanaidu N, Rohani $\mathrm{O}$ and Jalani S. Oil palm clones: current status and prospects for commercial production. The Planter. 1997; 73 (853): 163-184.

4. Kushairi A, Tarmizi AH, Zamzuri I, Ong-Abdullah M, Samsul Kamal R, Ooi SE and Rajanaidu N. Production, Performance and Advances in Oil Palm Tissue Culture. Malaysian Palm Oil Board, No. 6 Persiaran Institusi, Bandar Baru Bangi, 43000 Kajang, Selangor. 2010.

5. Zamzuri , Mohd Arif S, Rajanaidu N and Rohani O. Commercial feasibility of clonal oil palm planting material production. PORIM Occasional paper. 1999; 40: 52 pp.

6. Evans DA, Sharp WR, Ammirato PV, Yasuyuki Y. Handbook of plant cell culture. Techniques for propagation and breeding. Collier Mcmillan Publishers. 1983.

7. Vasil V and Hildebrandt AC. Differentiation of tobacco plants from single isolated cells in microcultures. Science. 1965; 150: 889-892.

8. Guha $\mathrm{S}$ and Maheshwari SC. In vitro production of embryo from anthers of Datura. Nature.1964; vol. 204 p. 497.

9. Carlson PS., Smith HH., Dearing RD. Parsexual interspecific plant hybridization. Proc. Nat. Acad. Sci. USA. 1972; 69: 2292-2294.

10. Steward FC, Mapes MO, Mears K. Growth and organized development of cultured cells. II. Organization in cultures grown from freely suspended cells. Am. J. Bot.1958; 45: 705-708.

11. Reinert J. Morphogenese und ihre kontrolle. An Gewebekulturen aus carotten. Naturwissenchaften .1958; 45: 344-345.

12. Reinert J. Uber die kontrolle der morphogenese und die induktion von advientiveembryonen an gewebekulturen aus karotten. Planta. 1959; 58: 318-333.

13. Jones LH. Propagation of clonal oil palm by tissue culture. Oil Palm News. 1974; 17: 1-8

14. Rabechault H, Ahee J, Guenin G. Colonies cellulaires et forms embryoides obtenues in vitro à partir de cultures d'embryons de palmier à huile (E. guineensis Jacq. var. dura Becc.) C.R. Acad. Sci. 1970; 270: 3067-3070.

15. Smith WK and Thomas JA. The isolation and in vitro cultivation of cells of Elaeis guinensis. Oleagineux. 1973; 28: 123-127

16. Ong HT. Studies into tissue culture of oil palm. In: Earp DA, Newall W (eds) International developments in oil palm. Incorporated Society of Planters, Kuala Lumpur. 1977; pp 9-15

17. Staritsky G. Tissue culture of the oil palm (Elaeis guineensis Jacq.) as a tool for vegetative propagation. Euphytica. 1970; 19: 288-292.

18. Schwendiman J, Panetier C, and Michaux-Ferriere N. Histology of somatic embryogenesis from leaf explants of the oil palm (Elaeis guineensis). Ann. Bot. 1988; 62: 43-52.

19. Corley RHV, Lee CH, Law LH, Wong CY. Abnormal flower development in oil palm clones. Planter. 1986; 62: 233-240.

20. Jones LH. An evaluation of the role of cytokinins in the development of abnormal inflorescences in oil palms (Elaeis guineensis Jacq.) regenerated from tissue culture. Journal of Plant Growth Regulation. 1995; 14 (3): 135-142.

21. Rival A, Bertrand L, Beulé T, Trouslot P, and Lashermes P. Suitability of RAPD analysis for the detection of somaclonal variants in oil palm (Elaeis guineensis Jacq.). Plant Breeding. 1998; 117 (1): 73-76.

22. Teixeira JB, Sondahl MR, and Kirby EG. Somatic embryogenesis from immature infloresecences of oil palm. Plant Cell Reports. 1994; 13 (5): 247- 250 . 
23. Rival A, Aberlenc-Bertossi F, Morcillo F, Tregear J, Verdeil J-L, Duval Y. Scaling-up in vitro clonal propagation through somatic embryogenesis: the case of oil palms: the example of oil palm (Elaeis guineensis Jacq.). Tissue Culture and Biotechnology. 1999; 3 (2): 7483.

24. Ruslan A. Large Scale propagation of clonal Palms: Some limitations, common problems and progress.PORIM - Int'l Palm Oil Congress. 1993; pp $122-134$.

25. Edwin FG and Sherrington PD. Plant propagation by tissue culture. Handbook and directory of commercial labotories. Exegetics limited. 1984.

26. Lydiane K and John K. Plants from Test Tubes. An Introduction to micropropagation. 3rd edition. Timber Press. Portland: Oregon. 1983.

27. Soh AC, Wong G, Tan CC, Chong SP, Choo CN, Nor Azura A, and Ho YW. Progress and challenges in commercial mass propagation of clonal oil palm. International oil palm conference. Nusa Dua-Bali, Indonesia. June 2006.

28. Khaw $\mathrm{CH}$ and $\mathrm{Ng}, \mathrm{SK}$. Performance of commercial scale clonal oil palm (Elaeis guineensis Jacq.) planting in Malaysia. Paper presented at Intl. Soc. Of Horticultural Science Symposium. Brisbane, Australia. 1997; 8pp.

29. Murashige T, and Skoog FA. Revised medium for rapid growth and bioassays with tobacco tissue culture. Physiol. Plant. 1962; 15:473497.

30. Eeuwens CJ, and Blake J. Mineral requirement for growth and callus initiation of tissue explants excised from mature coconut palms (Cocos nucifera L.) and culture in vitro. Physiol. Plant. 1976; 36:2328.

31. Tisserat B. In Bonja J.M., Durzan D.J. (eds). Cell and Tissue culture in forestry, M. Nijhoff Dordrecht. 1987; pp. 338-356

32. Chehmalee $\mathrm{S}$ and Te-chato $\mathrm{S}$. Induction of somatic embryogenesis and plantlet regeneration from cultured zygotic embryo of oil palm. Journal of Agricultural Technology. 2008; 4 (2): 137-146

33. Victor PG. Plant growth regulators in plant tissue culture and development. In: Trigiano R.N and Gray D.J. (eds) Plant Development and Biotechnology. CRC Press LLC, 2000 N.W. Corporate Blvd., Boca Raton, Florida 33431. 2005; 8: 87-100.
34. Abul-Soad AA, El-Sherbeny NR, Baker SI. Date palm (Phoenix dactylifera L. cv. Zaghloul) propagation using somatic embryogenesis of female inflorescence. 3rd Conference on Recent Technologies in Agriculture, Cairo University, Egypt, 14-16 Novembre 2005. 3: 423-441.

35. Branton RL and Blake J. Development of organized structures in callus derived from explants of Cocos nucifera L. Ann. Bot. 1983; 52:673-678.

36. Steinmacher DA, Clement CR and Guerra MP. Somatic embryogenesis from immature peach palm inflorescence explants: towards development of an efficient protocol. Plant Cell, Tissue and Organ Culture. 2007; 89:15-22.

37. Sharp WR, Sondahl MR, Caldas LS, and Maraffa SB. In: Horticultural Reviews, vol. 2. Janick J. ed. Avi Publishing Co, Westport, Conn., USA. 1980; p. 268.

38. George EF. Plant Propagation by tissue culture. Edington Wilts, Exergetics LTD. 1993.

\section{How to cite this article:}

Mondjeli Constantin, Walter Ajambang Nchu, NtsombohNtsefong Godswill, Ni Made Armini Wiendi, Ade Wachjar, Ngando Ebongue Georges Frank. Induction of oil palm (Elaeis guineensis Jacq. var. Tenera) callogenesis and somatic embryogenesis from young leaf explants. J App Biol Biotech. 2015; 3 (04): 004-010. 